\title{
EVOLUTION OF AEOLIAN LANDSCAPES IN NORTH-EASTERN ESTONIA UNDER ENVIRONMENTAL CHANGES
}

\author{
ANTO RAUKAS \\ Institute of Ecology at Tallinn University, Uus-Sadama 5, Tallinn 10120, Estonia; \\ E-mail address: anto.raukas@mail.ee
}

\begin{abstract}
Evolution of dunes and other aeolian landforms is characterized by phases of sand drift, alternated with geomorphic stability. Formation of wind-blown landforms in Estonia is strongly controlled by land uplift, climate, parent deposits, re-advance of ice-dammed lakes, as well as the Baltic Sea and Lake Peipsi water level changes. Different aeolian formations, such as coversand hillocks, blowouts, deflation hollows, foredunes, inland and coastal dunes, and wind-eroded plains are encountered. Forest cuttings and fires, military actions and other human activities triggered the movement of surficial sand, but wet environmental conditions, sparse population and rapid spreading of vegetation prevented extensive redistribution of loose sandy sediments by wind. In north-eastern Estonia, inland parabolic and transversal dunes were formed in severe climatic conditions of the Younger Dryas. Influence of climate is well seen also at the northern coast of Lake Peipsi, where rhythmically changing water level has caused aeolian redistribution of sediments.
\end{abstract}

Keywords: aeolian landforms, palaeoclimate, neotectonic uplift, inland and coastal dunes, Lake Peipsi, Estonia

\section{INTRODUCTION}

Natural aeolian mobility is influenced by climate, grain-size of parent deposits and vegetation cover. In Estonia, different wind-blown deposits and landforms, such as coversand hillocks, blowouts, deflation hollows, foredunes, inland and coastal dunes and wind-eroded plains are encountered (Fig. 1). The aeolian redistribution of fine aqueoglacial and beach material is highly controlled by land uplift, readvance of ice-dammed lakes, the Baltic Sea and Lake Peipsi water level changes, initial deposits and palaeoclimatic parameters (i.a., wind direction and activity, soil moisture). The stratigraphy and palaeoclimates of the Holocene (Raukas et al., 1995) and Late-Glacial (Pirrus and Raukas, 1996) are rather well studied in Estonia. Coversands are largely restricted to the areas with periglacial conditions favouring aeolian activity. In the north-eastern Estonia, inland parabolic and transversal dunes were formed in severe climate of the Younger Dryas. It is assumed that inland dunes started to develop here immediately following glacial deposition and re-advance of the ice-dammed lakes, when source deposits became available. Dune formation was stopped after stabilization of the sand movement by vegetation. Presently, the dunes are covered by pine forest and display podzolic soils.

The distribution and morphology of Holocene coastal dunes largely depends on the exposition of the beach ridges in the condition of gradual land uplift. Over a longer time span, the coastal zone is ever 
changing, its position swinging back and forth as a result of macro-climatic oscillations. The biggest dunes are related to the transgression phases of the Baltic Sea (Raukas, 1997). Owing to the moderate uplift of the Earth's crust, the shoreline in the Middle Baltic area was rather stable during the Baltic Ice Lake, Ancylus Lake and Littorina Sea transgressions and, therefore, the transgressive coastal formations are larger and higher, since the accumulation of the deposits was concentrated into a narrow zone. In the course of regressive phases, the shoreline retreated rapidly and beach erosion was less intensive, as a result of which less material was produced and deposited. Furthermore, under the conditions of a retreating shoreline, new segments of beach were exposed to shore processes for a short time, and all the depositional features are not clearly delineated.

The Littorina stage coincides with the classical Holocene climatic optimum. Together with the warming, the climate became more humid and eustatic water-level rise was remarkable. About 6,000-5,000 years ago the mean air temperature in the Baltic Sea area in the summer was approximately by 3 degrees higher than nowadays (Hyvärinen et al., 1988). During the Littorina Sea transgression (about 7,000 ${ }^{14} \mathrm{C}$ years, ca 7,800 calibrated years ago), a lot of sand accumulated in the coastal zone and the dune formation was intense.

As a result of the neotectonic uplift of the Earth's crust, ancient coastal dunes are nowadays situated at some distance from the contemporary shoreline and at different $a b-$ solute heights. At the present seashore, only low foredune ridges some metres high do occur, e.g., those at Kloogarand, Narva-Jōesuu and Valgerand. Dunes with specific morphology, called "basket-trap" dunes by Orvi$\mathrm{ku}$ (1933), are located on the northern coast of Lake Peipsi. Some small dunes occur also around Lake Vōrtsjärv (Tavast et al., 1983). In this paper, I shall analyse dune formation under the changing climate conditions on the Alutaguse Lowland and the northern coast of Lake Peipsi (Figs. 1 and 2).

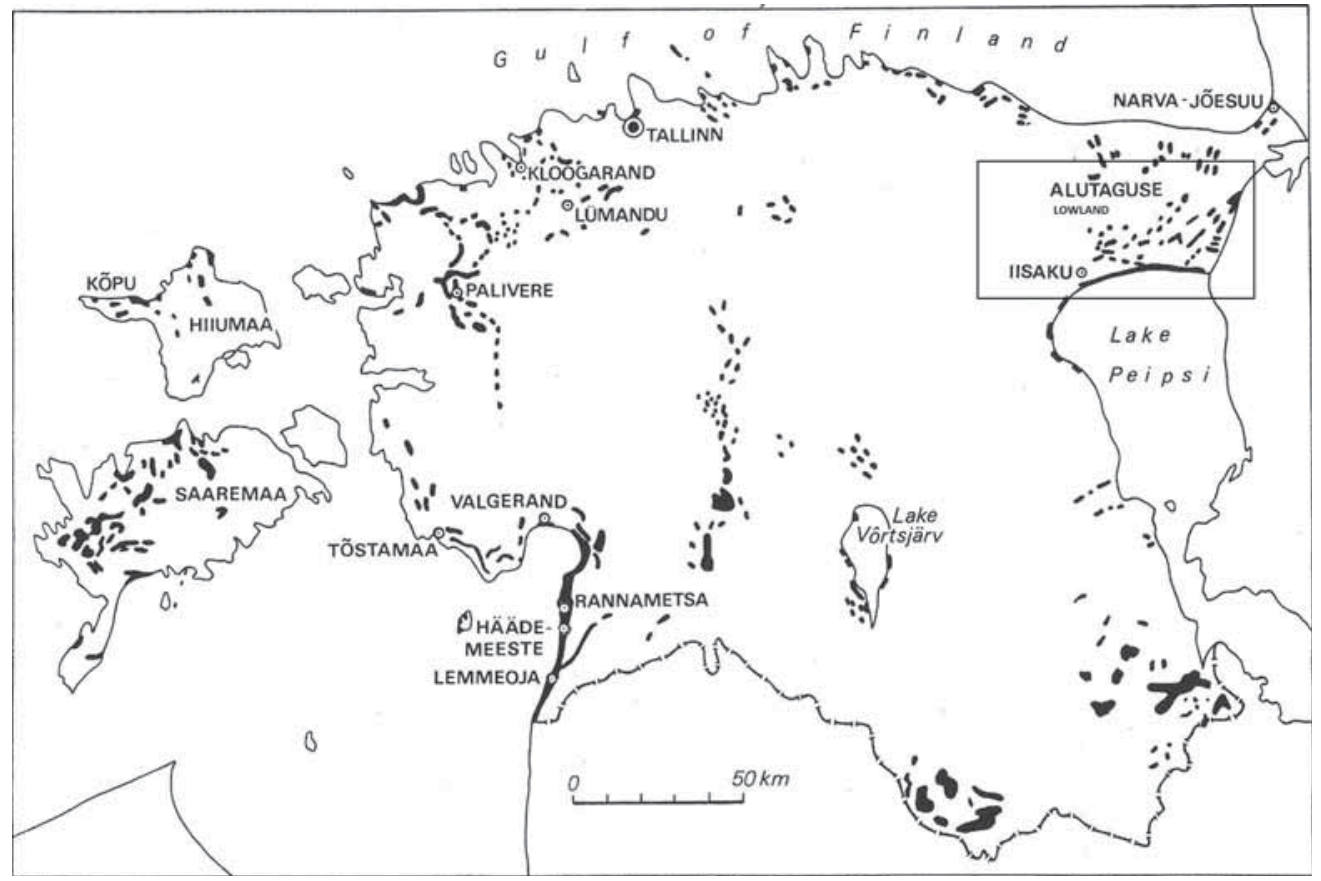

Figure 1. Distribution of aeolian landforms in Estonia and location of the study area 


\section{CONTEMPORARY SITUATION}

Due to the deficiency of sand, concentration of heavy storms in autumn and winter times and high precipitation rate, aeolian landforms in the contemporary coastal zone are relatively low (mainly up to $5 \mathrm{~m}$ ) and rendered stationary by vegetation. Due to moist and cold Sub-Atlantic climate, the movement of aeolian sands in Estonia is limited. However, moving sands were rather dangerous in the past. For instance, in the 19th century, many farmsteads were buried under wandering dunes. A shifting dune on the Island of Saaremaa threatened to destroy the Kärla church, pastor's mansion and farmsteads in the vicinity. The advance of the dune was stopped by young pines (Tiismann, 1924). The same author describes the movement of sand in the area of the Ristna lighthouse on the Island of Hiiumaa. The strong southwesters blew along a mass of sand, which piled up behind the doors and closed the entrance to the buildings. After each such storm the islanders had to work for days to cart the sand off. Kõpu lighthouse in Island of Hiiumaa, which became a functional lighthouse in 1649 , used about $800-1,000$ cords $(1$ cord $=$ 3.62 cubic metres) of firewood per year and it caused large-scale forest clearing and activation of aeolian processes.

Huge fields with a steppe-like appearance, which came into being in the 1950 s and 1960 s as a result of the intensification of agriculture and land improvement in the former Soviet Union, promoted deflation on sandy and peat soils. For instance, during April 9-May 11, 1974, 16.2 tons of dry soil per hectare were carried away from the Apometsa fields of the former Ranna State Farm, Harju County. On May 1-7 of the same year, from the fields of the Paluküla and Tubala villages on the Island of Hiiumaa, clouds of dust extended upwards for several tens of metres and posed a danger to the traffic. A layer of sand up to $30 \mathrm{~cm}$ in thickness was deposited on the road, being even thicker (up to $75 \mathrm{~cm}$ ) on the roadside. Particles of silty soil and dry peat start moving already at the velocity of wind as low as 3-4 $\mathrm{m} \mathrm{s}^{-1}$. How- ever, with the wind speed of about $15 \mathrm{~m} \mathrm{~s}^{-1}$, the amount of soil set into motion generates already a surface dust storm. In Estonia, the velocity of wind with gusts at a height of 10-20 m above the ground may reach 40 $\mathrm{m} \mathrm{s}^{-1}$. More persistent winds blowing with a speed of $35 \mathrm{~m} \mathrm{~s}^{-1}$ during several minutes cause great damage to agriculture. There are up to 200,000 hectares of land in danger of deflation in Estonia. In Island of Hiiumaa, such fields make up two-thirds of the whole arable land. When the danger was understood, fields larger than 50-60 hectares on lowlands and 20-30 hectares on elevations were prohibited. To reduce deflation, protective strips of forest of groves of trees were planted, while gentle peat soils were planned for a long-term use as grasslands. With the liquidation of the large-scale agriculture in Estonia, the area of fields endangered by wind erosion has essentially decreased.

\section{AEOLIAN ACTIVITY IN YOUNGER DRYAS}

In the light of pollen evidence, the deglaciation of the Estonian territory was completed at the end of Gotiglacial time during the second half of the Allerød Chronozone (Pirrus and Raukas, 1996). During the course of thinning of the ice sheet, several ice-marginal positions are represented in the modern topography. In northeastern Estonia, deposits and landforms of Sakala and Pandivere ice-marginal zones are presented. They were formed either as a result of standstills of the ice margin or short readvances (Raukas et al., 1971, 2004). The morphologically well-developed Younger Dryas continental dunes are located in the Iisaku area (Rähni, 1959) north of Lake Peipsi on both sides of the Iisaku-Illuka ice-marginal formations of the Pandivere Stadial (Fig. 2). Using different study methods and based on the data available in the study area and its neighbourhood, the age of the Pandivere belt is ca $12,300{ }^{14}$ C years (Raukas, 2009).

The Allerød Chronozone in Estonia is divided into two parts (Pirrus and Raukas, 1996): (a) Pinus-Betula zone and (b) Pinus 


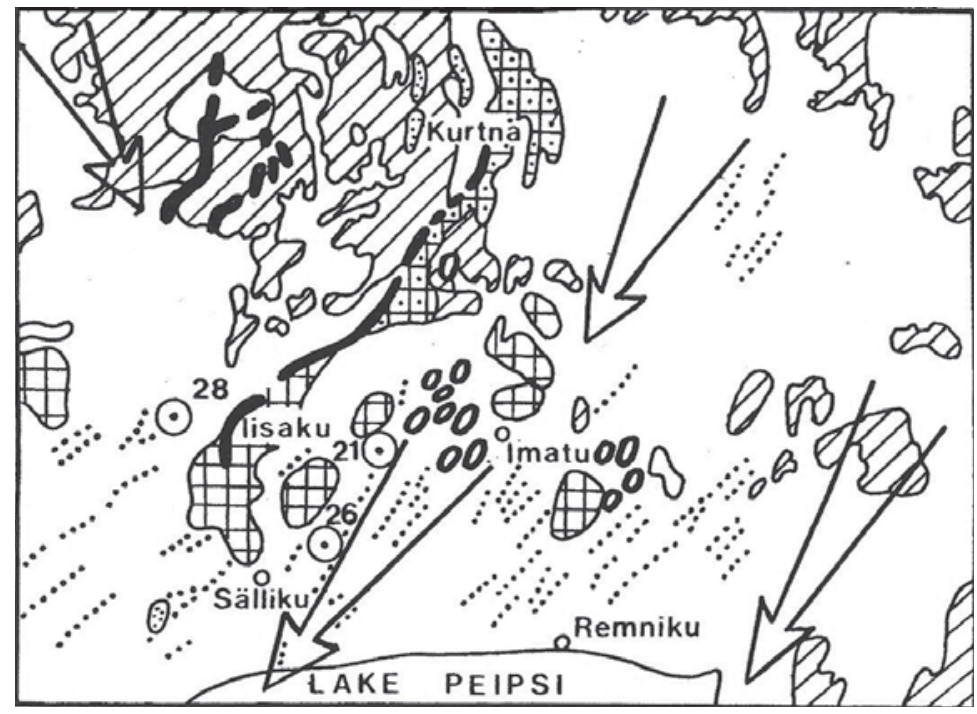

Figure 2. Glacial topography and inland dunes in the Iisaku area: 1 - till plain; 2 - glaciolacustrine plain; 3 -drumlins, 4 - eskers; 5 - kame terraces and limnoglacial plateaus; 6 - kames; 7 - inland dunes; 8 - ice movement; 9 - boreholes with OSL-dated aeolian deposits

zone. The boundary between these zones is fixed with a distinct increase of Pinus (up to 80-91\%) and continuous decrease of herbs and Betula nana L. Characteristic of the Allerød Chronozone is the prevalence of tree pollen. At the same time herb pollen is at its lowest. Xerophytes, halophytes, heliophytes, and tundra plants are present but in low values.

The zonal boundary between the Allerød and Younger Dryas is placed at the strong and rapid increase of the content of herb pollen (particularly Artemisia, in north Estonia usually over 70\%) and Betula nana L. (Pirrus and Raukas, 1996). Tundra plants (Dryas octopetala L., Selaginella selaginoides (L,) Link, Ledum palustre L., Rubus chamaemorus L., Botrychium boreale (Fr.) Milde, Lycopodium pungens La Pyl., Lyc. alpinum L.) are found in considerably increased contents. The representation of Chenopodiacea is frequent, in north Estonia 9-25\%. Different amounts of the pollen and spores of mesoxerophilous (Chenopodium album L., Ch. Glaucum L.), xerophilous (Eurotica ceratoides (L.), Polycnemum, Salsola ruthenica Iljin), and halophilous (Sal- sola kali L., Salicornia europaea L., Kochia prostrata (L.) Schrad) species along with Ephedra, Hippophae rhamnoides L. and $\mathrm{He}$ lianthemum are present.

In the dry and cool Younger Dryas Chronozone in Estonia, like all over Europe (Koster, 1988), favourable conditions for the activation of aeolian processes did exist. Aeolian phases started when glaciolacustrine dry sands and silts were exposed after the drainage of ice-dammed lakes, and following ground water level lowering (partly due to land uplift). In North-East Estonia, in the Iisaku area (Fig. 2), inland dunes are described on the territory of about $50 \mathrm{~km}^{2}$. Parabolic and transversal dunes indicate a westerly-north-westerly palaeo-wind directions (Zeeberg, 1993). Dunes are 0.8-2.7 km long and up to $15-20 \mathrm{~m}$ high (Fig. 3). Their western and north-western windward slopes are slanting $\left(3-18^{\circ}\right)$, while the opposite leeward slopes are much steeper $\left(18-24^{\circ}\right)$. On the top and slopes of dunes small coversand hillocks occur. It is possible that in some places aeolian sands cover limnoglacial kames and the morphology and orientation of dunes is dependent on glacial topography. 


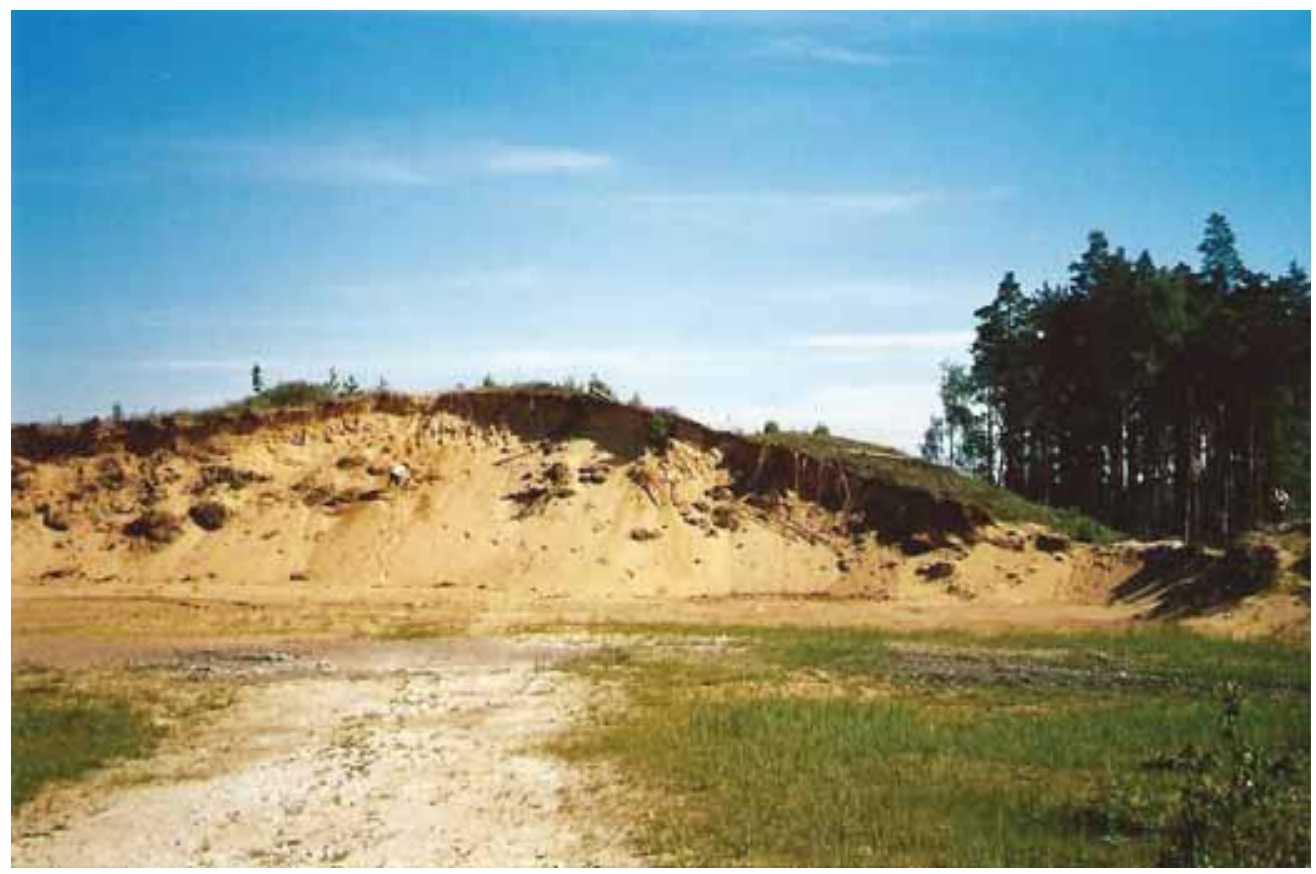

Figure 3. Small inland dune at Sälliku; 5th June 2007.

Source: Photo by the Author.

These dunes and drift sands originated from the Younger Dryas and the beginning of the Preboreal, when in the Alutaguse Lowland a significant regression of ice-dammed lakes took place and the so-called Small Peipsi was formed (Raukas and Rähni, 1969). Aeolian sand and silt were derived here from local source material, e.g., from glaciofluvial and glaciolacustrine deposits reworked by the ancient Lake Peipsi. Dunes were commenced here immediately after source deposits became available and the process stopped when they became overgrown with vegetation.

Nowadays, the inland dune areas in northeastern Estonia are surrounded by peat bogs and covered by pine forests. Their maximum ages may be inferred from the sediments or soils on which the dunes started to develop. These, mostly glaciolacustrine plains and kame fields, formed some 12,200-12,300 ${ }^{14} \mathrm{C}$ years ago (Raukas et al., 1971). However, the sand became available for redeposition only after it had drained and dried, possibly after the retreat of the glacier of the Palivere Stadial some 11,000 ${ }^{14} \mathrm{C}$ years ago (Raukas, 1992).

Unfortunately, this cannot be checked by palynological sampling of dune sands or dating of organic remains. In 1988, attempts were made to solve the problem by means of the OSL-method (Raukas and Hütt, 1988), however, all the dates obtained suggested much younger ages: in borehole 21 from 4,000 to 5,900 , in borehole 28 from 3,000 to 6,900 , and in borehole 26 between 4,700 and 7,100 years BP (Fig. 2). It is well-known that the history of dunes is characterized by phases of sand drift, alternated with geomorphic stability. Therefore, our dates show the multiple redeposition of initial Younger Dryas glaciolacustrine and aeolian sediments. Forest cuttings and fires, military actions and other human activities may trigger the movement of the sand surface here also nowadays, but wet environmental conditions, sparse population and rapid spreading of vegetation prevented ex- 
tensive redistribution of loose sandy sediments by wind.

\section{COASTAL DUNES OF LAKE PEIPSI}

The Estonian coastal dunes are scattered all over Low-Estonia where sand-silty sediments necessary for their formation were available (Fig. 1). The largest dunes, up to $20-25 \mathrm{~m}$ in height, formed during the transgressive phases of the Baltic Ice Lake, Ancylus Lake and Littorina Sea (Eltermann and Raukas, 1966). Rising sea levels lead to shoreline erosion, destruction of fore-dune and beach ridge vegetation, and initation of transgressive dunes (Cooper, 1958). The greatest number of dunes occur on the west-facing shores, where the prevailing winds are westerlies and south-westerlies.

Another situation typifies the coast of Lake Peipsi, where biggest dunes occur in the northern coast being formed by southerly winds. Due to land uplift and changing erosion of the coast, one can see here an uneven migration of aeolian material, during which the central ridge blowouts moved downwind and the low-lying arms fixed with vegetation lag behind, and parabolic dunes came into being. Both the ridge of parabolic dunes and the fields made up of such dunes contain multiple reaping-look segments. Erosional forms in dunes are a few metres deep. In such dunes, the windward slope has an inclination of $10-20^{\circ}$ and the leeward slope $20-30^{\circ}$.

Directly on the coast, specific "basket-trap dunes" (according to Orviku, 1933) are common. These dunes were formed behind rather huge parabolic wind ditches, which developed at the sites where the vegetation cover had been locally breached as a result of damage to vegetation by wave erosion and ice action (Fig. 4) or by clearing, grazing, burning or trampling. Onshore winds have developed blowouts, hollows cut through a foredune or ancient dune, with a nose of sand spilling inland. Most blowouts feature an asymmetric profile, with moisture and frost producing over-steepened south-facing slopes that are subject to seasonal collapse. Detailed studies of blowout morphology have revealed a complex pattern of sediment redistribution involving both aeolian and slope processes. Migration of sand manifests itself most clearly from June to September, when the load of holiday makers is high and much trampling is done.

With no doubts the biggest agent is seasonally and annually changing wave erosion. The water level in Lake Peipsi undergoes considerable fluctuations, being lowest in summer and autumn/winter periods. Long-term observations have revealed a distinct rhythmicity in lake level fluctuations, which may be due to solar activity (Fig. 5). In the recent past, during 1959-1977, the water level in the lake was lower than the long-term average. During the water-rich period 1986-1991, it was $0.5 \mathrm{~m}$ above the long-term average. Since 1992 the water level has been constantly lowering. In 1996, it was extremely low and in some places the lake floor was exposed for several hundreds of metres and small foredunes started to accumulate on the coast (Fig 6). Now a new high-water period has started as expected in several publications (i.a., Jaani and Reap, 2001). Due to the considerable water-level fluctuations in the lake, both the surface area and the volume of the lake water vary greatly. During the highest water level (12 May, 1924; $31.76 \mathrm{~m}$ ) the surface area of L. Peipsi was estimated at $4,330 \mathrm{~km}^{2}$ and the volume of water at $32.128 \mathrm{~km}^{3}$. At the lowest water level (7 November, 1994; 28.72 m), these values were $3,480 \mathrm{~km}^{2}$ and $20.98 \mathrm{~km}^{3}$, respectively. Thus, the surface area of the lake may vary by $850 \mathrm{~km}^{2}$, and the water volume by $11.15 \mathrm{~km}^{3}$. The maximum amplitude of water level fluctuations is $3.04 \mathrm{~m}$ (Jaani, 2001).

Sedimentary coastal landscapes are relatively unstable. Coastal dunes can be built up or washed away by the lake rather fast. It is understandable that the erosion and damages on the coast highly depend on the climatically induced water level. During the low-level periods no erosion will be noted and a broad, up to a kilometre-wide foreshore plain will emerge. When the water 


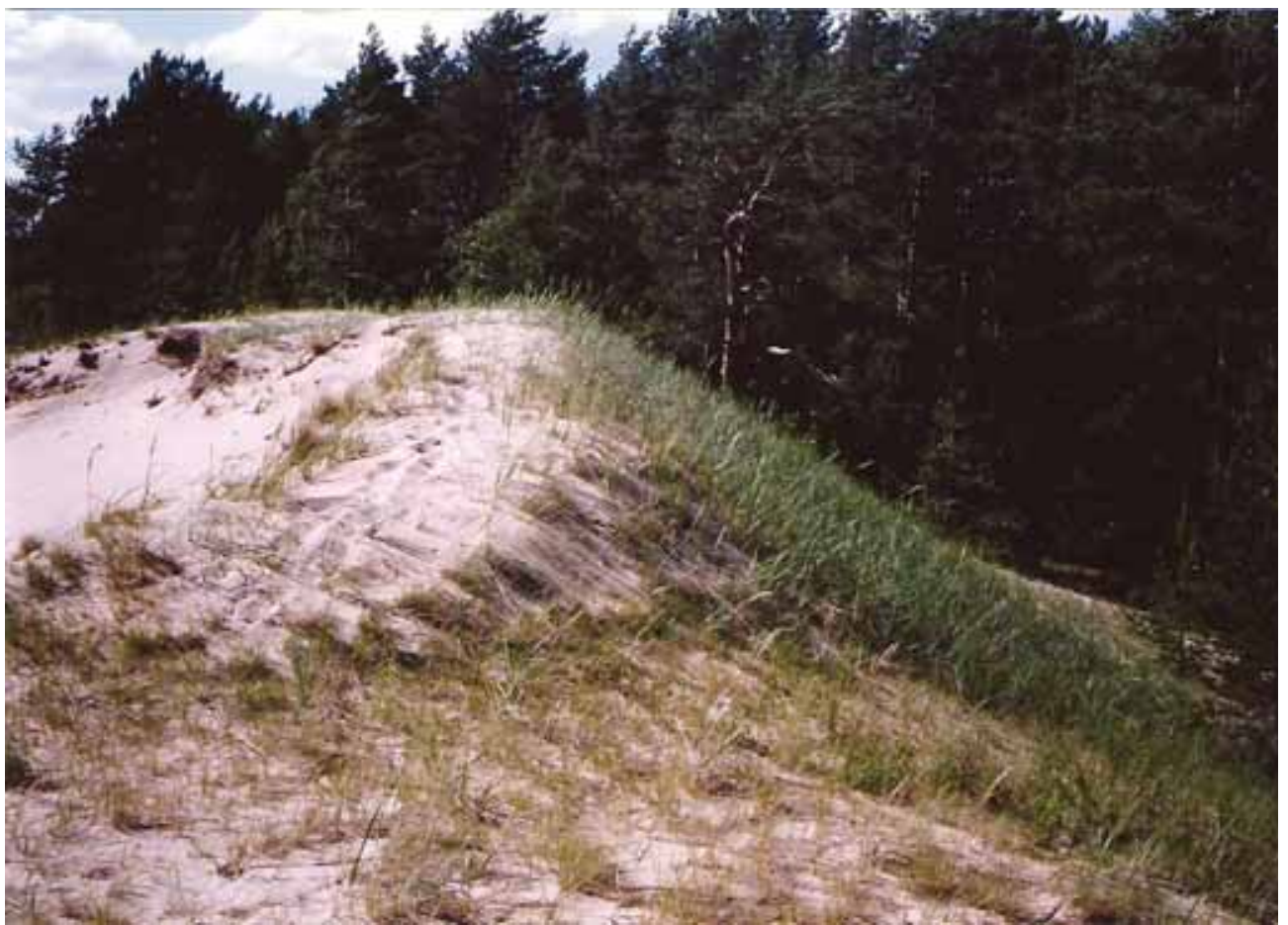

Figure 4. "Basket-trap dune" formed behind a parabolic wind ditch at Kuru; 18th June 1998.

Source: Photo by the Author.

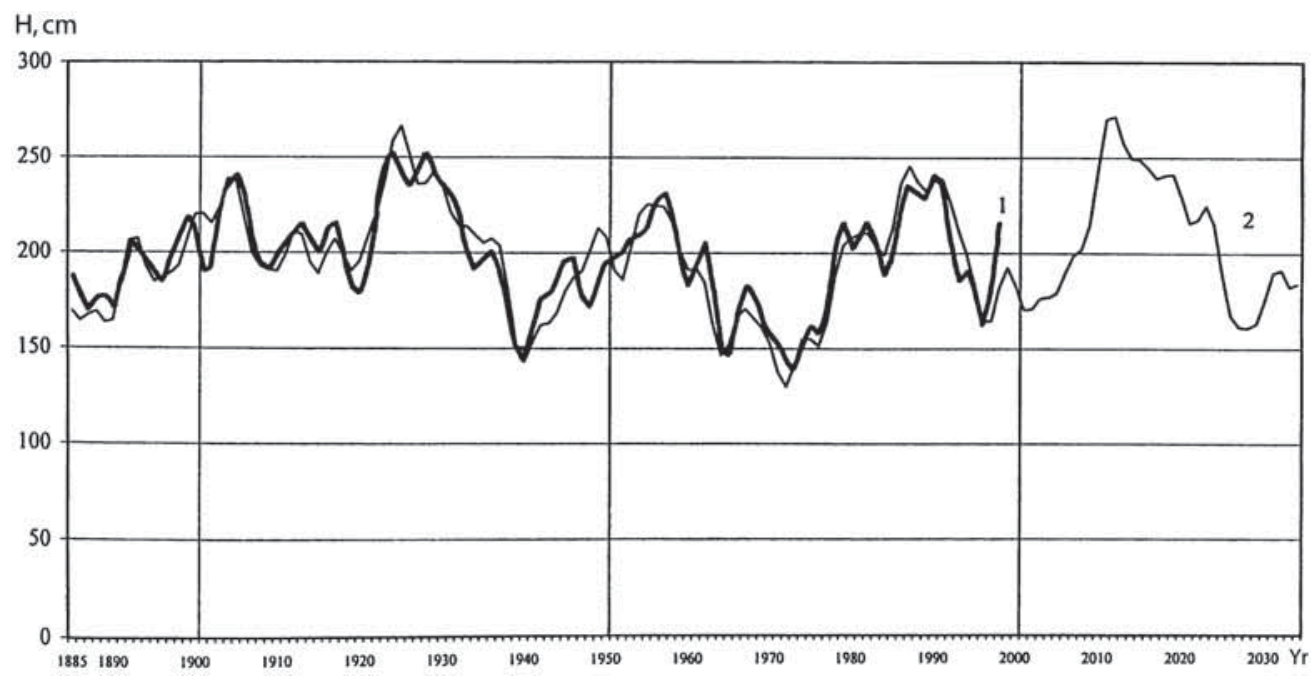

Figure 5. Predicted water abundance for Lake Peipsi

(mean annual water levels, 3 - year moving average): 1 - water level according to measured data; 2 - computed water levels (after Jaani and Reap, 2001) 


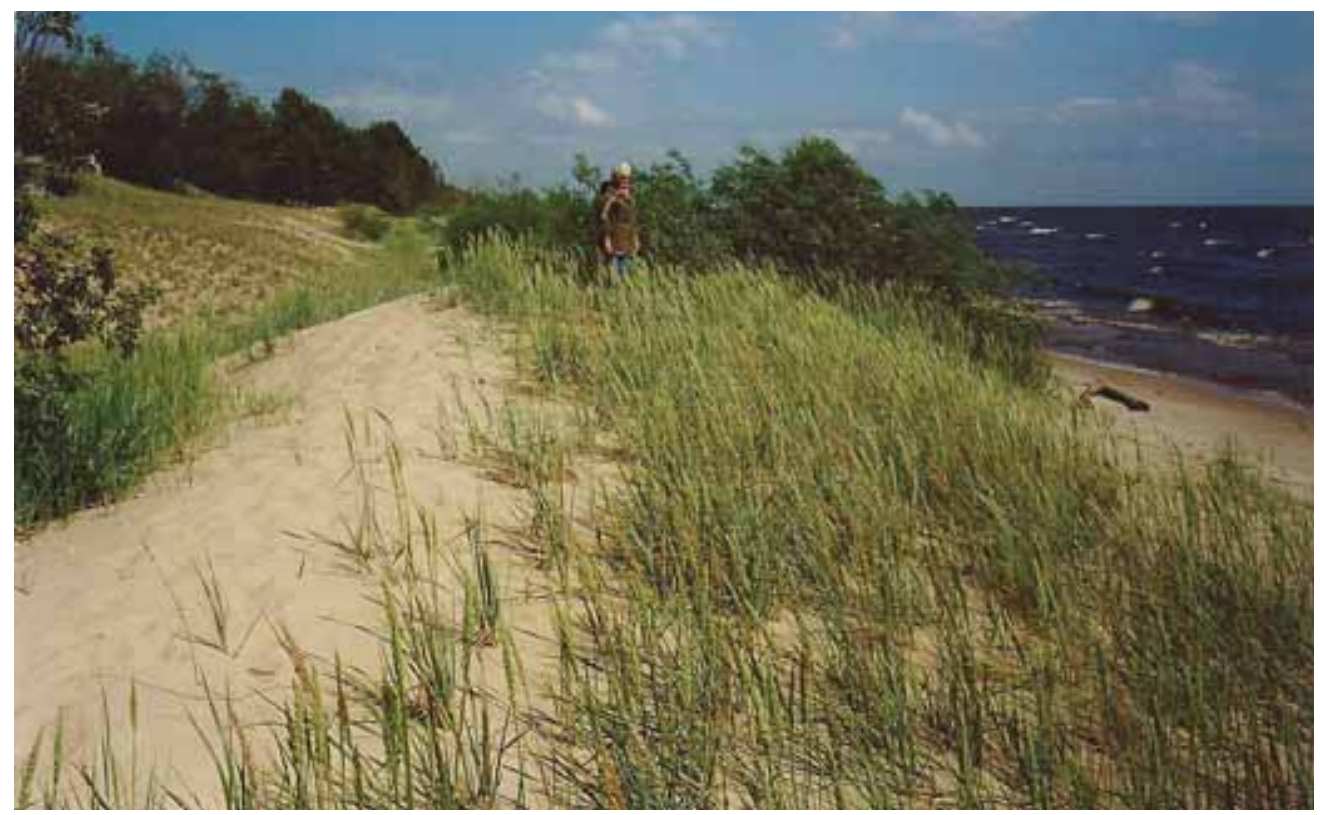

Figure 6. Small foredune formed during low stand of water in 1996-97 at Remniku; 17th June 1998.

Source: Photo by the Author.

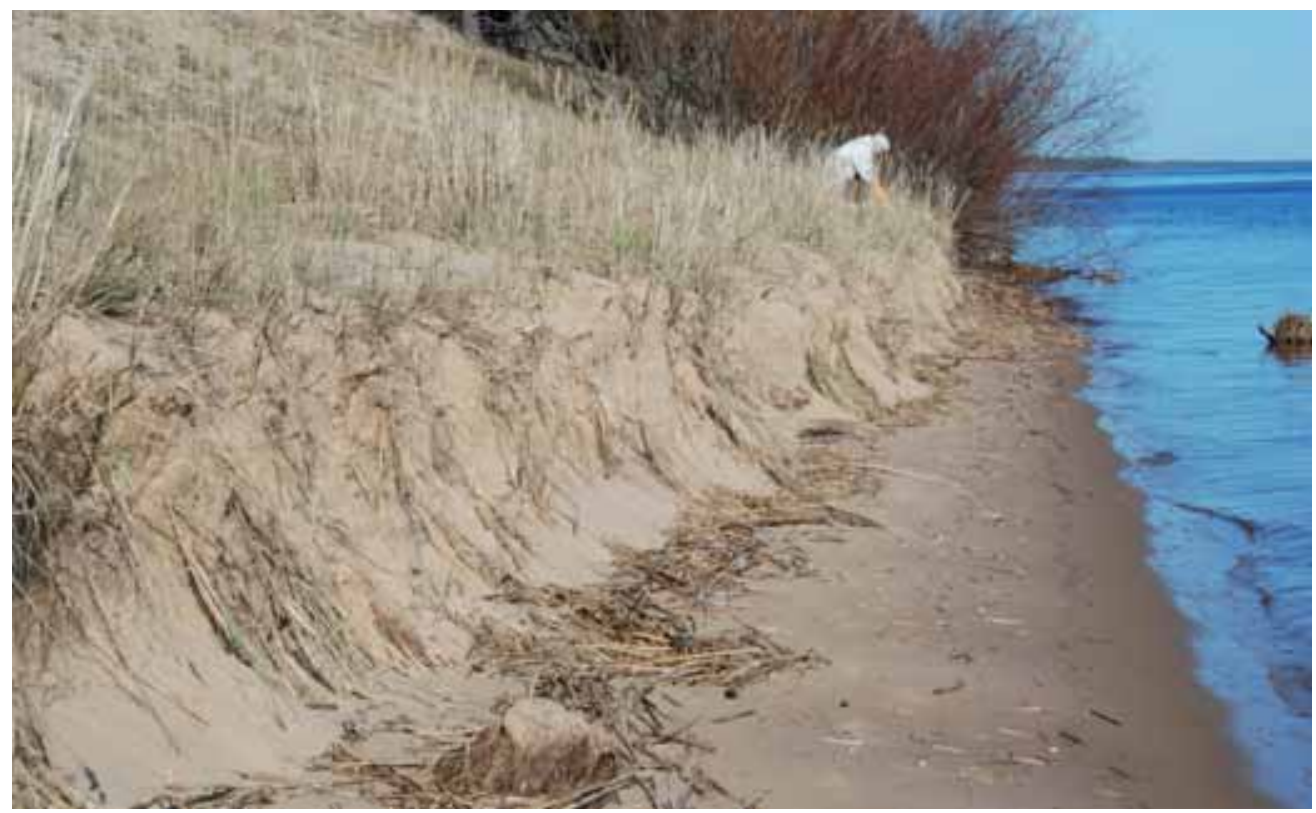

Figure 7. Coast at Remniku after heavy storm during high stand of water on the 21st May 2009.

Source: Photo by the Author. 
level rises, the lake shores will be subject to intensive erosion and serious damage. As already mentioned, during low stands of water small foredunes will form on the coast. Soon these accumulations become owergrown with plants (Fig. 6) and are eroded during high stand of water (Fig. 7).

\section{CONCLUSION}

In Estonia, we can see clear influence of the climate and land uplift on the aeolian redistribution of fine aqueoglacial and beach material starting from the Late-Glacial up to nowadays. In North-East Estonia inland parabolic and transversal dunes were formed in severe climatic conditions of the Younger Dryas. The Littorina Sea transgression (about $7,000{ }^{14} \mathrm{C}$ years, ca 7,800 calibrated years ago) witnessed an eustatic sea-level rise and a lot of sand accumulated in the coastal zone. The dune formation was especially intense at that time. On the northern coast of Lake Peipsi, due to big climatically-induced water level fluctuations, erosion of older dunes and formation of new-ones is observed.

\section{ACKNOWLEDGEMENTS}

First, I would like to thank my Polish colleagues Prof. Dr. Marek Degórski and Assoc. Prof. Dr. Zofia Raczkowska for inviting me to contribute a paper to this volume dedicated to my old friend and colleague Professor Leszek Starkel, an initiator and leader of many outstanding projects in Quaternary research. My research was supported by the Estonian Ministry of Education and Research (target project SF0280016607) and the Estonian Science Foundation (grant No 7392).

\section{REFERENCES}

Cooper, W.S. (1958), Coastal sand dunes of Oregon and Washington, Geological Society of America, Memoirs, 72: 1-169.
Eltermann, G. and Raukas, A. (1966), Eesti luidetest [Estonian sand dunes], Eesti Loodus, 1: 12-18 (in Estonian with Russian and English summaries).

Jaani, A. (2001), Lowering of the water level of Lake Peipsi, in Nõges, T. (ed.), Lake Peipsi. Meteorology. Hydrology. Hydrochemistry, Sulemees Publishers, Tartu, 45-46.

Hyvärinen, H., Donner, J., Kessel, H. and Raukas, A. (1988), The Litorina Sea and Limnea Sea in the Northern and Central Baltic, in Donner, J. and Raukas, A. (eds), Problems of the Baltic Sea History. Annales Academiae Scientiarum Fennicae, series A, III. Geologica-Geographica, 148: 25-35.

Jaani, A. and Reap, A. (2001), Water level prognosis for the near future, in Nõges, T. (ed.), Lake Peipsi. Meteorology. Hydrology. Hydrochemistry, Sulemees Publishers, Tartu, 47.

Koster, E.A. (1988), Ancient and modern cold-climate aeolian sand deposition: a review, Journal of Quaternary Science, 3: 69-83.

Orviku, K. (1933), Tuiskliiv [Drifting sand], Tartu K/Ü Loodus, Tartu.

Pirrus, R. and Raukas, A. (1996), Late-Glacial Stratigraphy in Estonia, Proceedings of the Estonian Academy of Sciences, 45, 1: 34-45.

Raukas, A. (1992), Ice-marginal formations of the Palivere zone in the Eastern Baltic, Sveriges Geologiska Undersökning, Ser. Ca, 81: 277-284.

Raukas, A. (1997), Aeolian activity, in: Raukas, A. and Teedumäe, A. (eds), Geology and Mineral Resources of Estonia, Estonian Academy Publishers, Tallinn, 290-293.

Raukas, A. (2009), When and how did the continental ice retreat from Estonia? Quaternary International, 207: 50-57.

Raukas, A. and Hütt, G. (1988), On the Luminescence Dating of Eolian Deposits in Estonia, Baltica, 11: 17-24.

Raukas, A., Kalm, V., Karukäpp, R. and Rattas, M. (2004), Pleistocene glaciations in Estonia, in: Ehlers, J. and Gibbard, P.L. (eds), Quaternary Glaciations - Extent and Chronology, Part I: Europe, Elsevier, Amsterdam, 83-91.

Raukas, A. and Rähni, E. (1969), O geologicheskom razvitii vpadiny $\mathrm{i}$ basseinov Chudskogo i Pskovskogo ozyor [On the geological development of the Peipsi-Pihkva depression 
and the basins distributed in that region], Eesti NSV Teaduste Akadeemia Toimetised. Keemia, Geoloogia, 18, 2: 113-127 [in Russian with English summary].

Raukas, A., Rähni, E. and Miidel, A. (1971), Kraevye lednikovye obrazovania Severnoi Estonii [Marginal glacial formations in North Estonia], Valgus, Tallinn, [in Russian, with English summary].

Raukas, A., Saarse, L. and Veski, S. (1995), A new version of the Holocene stratigraphy in Estonia, Proceedings of the Estonian Academy of Sciences, 44, 4: 201-210.

Rähni, E. (1959), Iisaku-Illuka ooside ala [The esker district of Iisaku-Illuka], Eesti Loodus, 1: 16-22.
Zeeberg, J.J. (1993), Aeolian redistribution of glacial silt and sand in Estonia and the Baltic Region, Institute of Geographical Research Utrecht Rapport, 12: 1-98.

Tiismann, B. (1924), Hiiusaare rannikuluited, nende kinnistamine ja metsastamine [Coastal dunes of Hiiumaa Island, their fixing and afforestation], Tartu Ülikooli Metsaosakonna Toimetused, 1: 1-95.

Tavast, E., Raukas, A. and Moora, T. (1983), Kallast mööda ümber Vōrtsjärve [Circling Lake Võrtsjärv along its shores], Eesti Loodus, 6: 364-373.

Paper first received:April 2011

In final form: August 2011 